\title{
Reef formation versus solitariness in two New Zealand serpulids does not involve cryptic species
}

\author{
Abigail M. Smith ${ }^{1, *}$, Zoe E. Henderson ${ }^{1}$, Martyn Kennedy ${ }^{2}$, Tania M. King ${ }^{2}$, \\ Hamish G. Spencer ${ }^{2}$ \\ ${ }^{1}$ Department of Marine Science, University of Otago, Dunedin, New Zealand \\ ${ }^{2}$ Allan Wilson Centre for Molecular Ecology and Evolution, Department of Zoology, University of Otago, Dunedin, New Zealand
}

\begin{abstract}
Tissue from both solitary and aggregated serpulids Galeolaria hystrix and Spirobranchus cariniferus from southern New Zealand was sequenced using 18S, histone H3 and cytochrome $b$ in order to determine whether these differences in ecology and lifestyle reflect the existence of cryptic species. In both cases, all 3 phylogenetic trees unequivocally combined solitary and aggregated individuals into 2 monophyletic groups corresponding to the nominal species. Some combination of larval behaviour, adult attractants and biotic/physical environmental factors are likely to be the drivers of reef formation in these serpulid worms. A previously sequenced Australian specimen of G. hystrix is not in the same clade as the New Zealand samples and requires re-investigation.
\end{abstract}

KEY WORDS: Polychaeta $\cdot$ Serpulidae $\cdot$ Galeolaria $\cdot$ Spirobranchus $\cdot$ Temperate reefs

\section{INTRODUCTION}

Serpulid worms (Annelida: Polychaeta: Sabellida: Serpulidae) are benthic suspension-feeders with a characteristic calcareous tube and a tentacular crown. About $10 \%$ of known species can sometimes grow in groups of tubes tangled together in aggregations which can grow upwards to form reefs up to a few metres in height and several kilometres in length (ten Hove \& van den Hurk 1993). Although serpulid reefs have been studied for more than a century (e.g. Nardo 1847, Mörch 1863), the factors promoting aggregation are not well understood (Bosence 1973, ten Hove 1979). All species that occur in aggregations are also found as individuals (ten Hove \& van den Hurk 1993).

In southern New Zealand there are 2 common aggregating serpulid worms (Fig. 1): Galeolaria hystrix Mörch, 1863 and Spirobranchus cariniferus
(Gray, 1843) ${ }^{1}$. G. hystrix occurs in intertidal to subtidal waters ( 0 to $10 \mathrm{~m}$ ) as solitary individuals (some on rocks and others in sand), and also in deeper waters $(10$ to $20 \mathrm{~m})$ of Paterson Inlet, Stewart Island, in aggregated patch reefs (Smith et al. 2005). $S$. cariniferus occurs as individuals or in patchy or beltlike aggregations in the lower intertidal zone of New Zealand north of about $45^{\circ} \mathrm{S}$ latitude (Morton \& Miller 1973, as Pomatoceros caeruleus).

Morphologically similar serpulids can exhibit differences in habit. For example, Bastida-Zavala \& ten Hove (2002) noted that 4 species of western Atlantic

\footnotetext{
15ome authorities (e.g. ten Hove \& Kupriyanova 2009) refer to $S$. cariniferus as $S$. carinifer, being of the view that this formation has the correct masculine ending to agree with the masculine genus name. Our consultation with Latin scholars, however, suggests both carinifer and cariniferus are correctly masculine (see also Herbert 1993); hence, we use Gray's original form of the name
} 

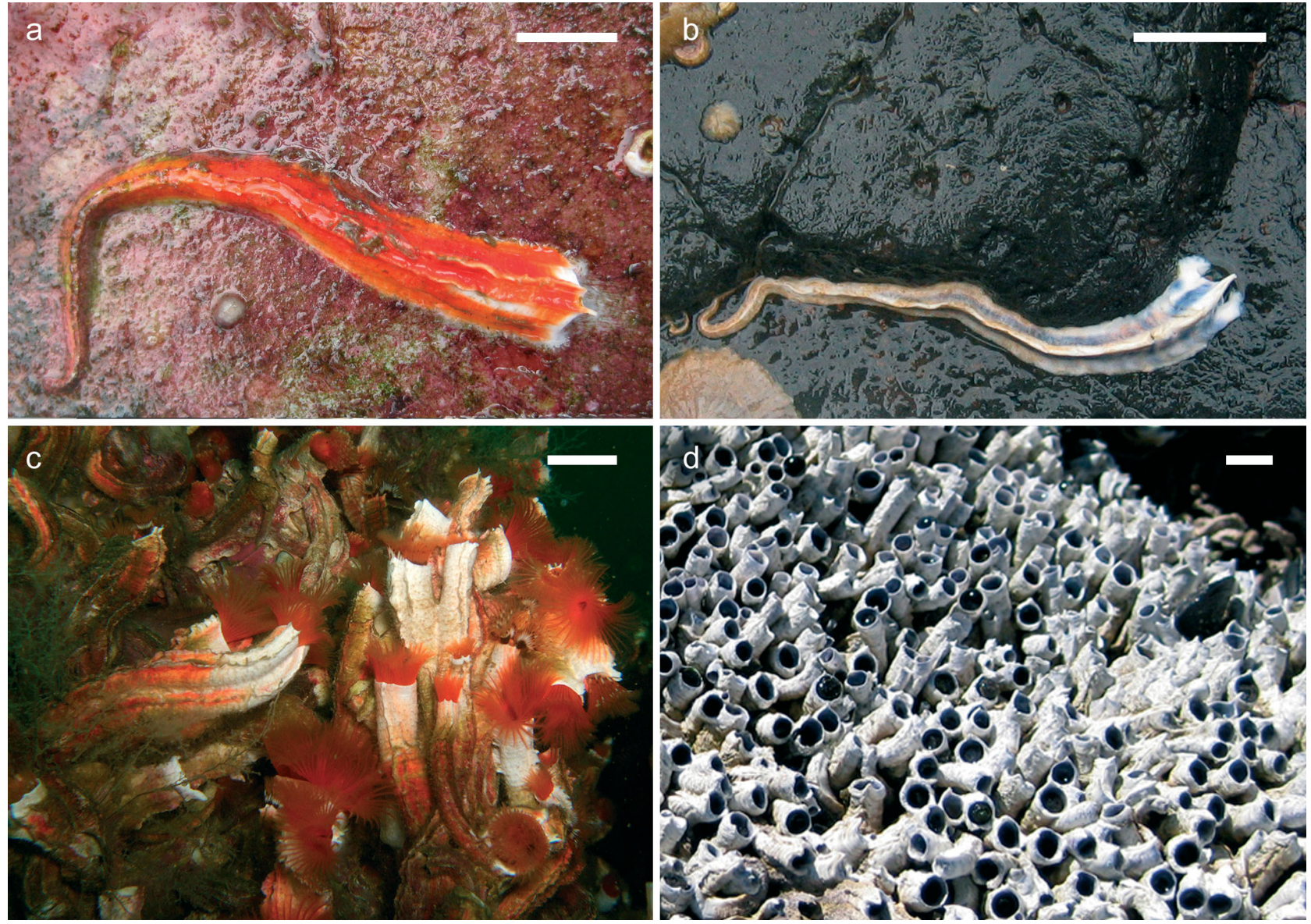

Fig. 1. Galeolaria hystrix and Spirobranchus cariniferus. (a) Solitary G. hystrix, settling plate, Big Glory Bay, Stewart Island, New Zealand (NZ); (b) solitary S. cariniferus, rock, Otago Harbour, NZ; (c) aggregated G. hystrix, seafloor, Big Glory Bay; (d) aggregated $S$. cariniferus, intertidal rocks, Sumner Beach, NZ. Photos by: M. A. Riedi and A. M. Smith. Scale bars are all $1 \mathrm{~cm}$

Hydroides (H. spongicola, H. elegantulus, H. floridanus and $H$. alatalateralis) were 'very similar' and distinguishable chiefly by minute morphological differences (the length of wings along opercular spines and the numbers of radioles, raduli and spines), but the first was apparently restricted to living in association with a particular species of sponge. Though it is commonly theorised that environmental factors induce subtidal aggregation (e.g. ten Hove 1979), we know of no studies that have examined cryptic species diversity as a possible explanation of these ecological differences.

Here we address the hypothesis that different modes of life in 2 species of southern serpulid worms, Spirobranchus carinferus and Galeolaria hystrix, are in fact reflections of such diversity, i.e. the aggregating population is a different cryptic species from the solitary population in each of 2 common species. We note that the related Australian nominal taxon, G. caespitosa, has recently been found to consist of 2 morphologically indistinguishable but genetically distant species (Halt et al. 2009).

\section{MATERIALS AND METHODS}

Specimens of solitary (i.e. individuals not touching another conspecific tube) and aggregated Galeolaria hystrix and Spirobranchus cariniferus as well as outgroup species from the serpulid genera Protula and Salmacina and the subfamily Spirorbinae were collected from southern New Zealand (Table 1) between November 2010 and March 2011. DNA was extracted from either the branchial crown or a larger region of the dorsal part of the body for smaller spirorbids, using a Purelink ${ }^{\mathrm{TM}}$ Genomic DNA Mini Kit (Invitrogen).

A combination of mitochondrial (cytochrome $b$ ) and nuclear (histone H3 and 18S) genes were used to check for concordance between these types of mark- 
Table 1. Serpulid worm species collected for this study, location and water depth of collection, and mode of life (aggregated or solitary), along with the number of individuals sequenced per gene. Hist: histone; Cyt $b$ : cytochrome $b$

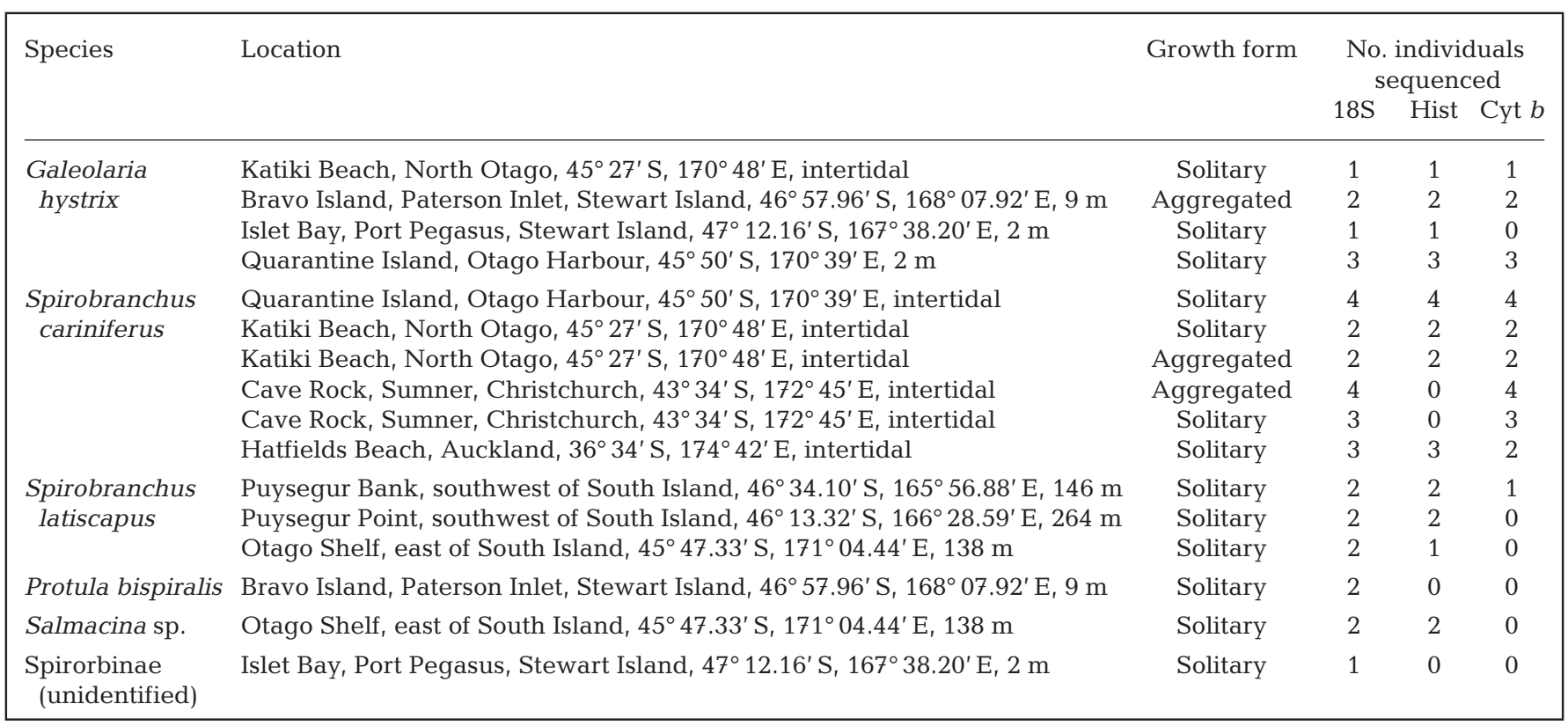

ers. Each of these markers evolves at a different rate and thus provides a different level of resolution. Approximately $1800 \mathrm{bp}$ of $18 \mathrm{~S}$ was amplified using primers TimA (Norén \& Jondelius 1999) and 18s2R (Kupriyanova et al. 2006), 300 bp of histone H3 using $\mathrm{H} 3 \mathrm{aF}$ and H3aR (Colgan et al. 1998) and $350 \mathrm{bp}$ of cytochrome $b$ using Cytb424F and cobr825 (Halt et al. 2009). All reactions were carried out in $20 \mu \mathrm{l}$ volumes and contained $0.5 \mu \mathrm{M}$ of each primer and $0.5 \mathrm{U}$ MyTaq Red DNA polymerase (Bioline). Amplifications were performed using an Eppendorf Mastercycler ep Gradient $\mathrm{S}$ thermal cycler with a cycling profile of $94^{\circ} \mathrm{C}$ for $120 \mathrm{~s}$, followed by 45 cycles of $94^{\circ} \mathrm{C}$ for $30 \mathrm{~s}$, $45^{\circ} \mathrm{C}$ for $30 \mathrm{~s}$ (increased to $48^{\circ} \mathrm{C}$ and $120 \mathrm{~s}$ for $18 \mathrm{~S}$ ) and $72^{\circ} \mathrm{C}$ for $60 \mathrm{~s}$ and a final extension of $72^{\circ} \mathrm{C}$ for $240 \mathrm{~s}$. PCR products were run on $1 \%$ agarose gels containing SYBR Safe DNA gel stain (Life Technologies) and visualized under blue light (Uvitec UVIdoc HD2/ 20Blue). Bands were either purified directly or gel purified using an E.Z.N.A. Ultra-Sep Gel Extraction Kit (Omega Bio-Tek). Purified PCR products were quantified using a ND-1000 spectrophotometer (Nanodrop) and sequenced by University of Otago Genetic Analysis Services using an ABI 3730xl DNA analyser using either the PCR primers or, for 18S, internal primers 18s2F and 1100R2 (Kupriyanova et al. 2006).

Sequences were edited and aligned using ClustalW2 within Sequencher 4.10.1 (Gene Codes). A BLAST search confirmed the correct gene regions had been amplified (Altschul et al. 1990) and the new sequences were submitted to GenBank (accession numbers JX144795-JX144879).

The 3 separate genes are treated individually in the following analysis as we wished to evaluate the information in the nuclear and mitochondrial markers separately. Phylogenetic analyses were performed with MrBayes (Huelsenbeck \& Ronquist 2001, Ronquist \& Huelsenbeck 2003) for Markov chain Monte Carlo Bayesian analysis and posterior probabilities and PAUP* v.4b10 (Swofford 2002) for maximum parsimony (MP) and neighbour-joining (NJ) bootstrap searches (Felsenstein 1985). For visualization purposes, and because of the different taxa in each data set, different taxa were defined as the outgroup taxa for 18S (Spirorbinae) and histone H3 (Protula bispiralis and Salmacina sp.) data sets, with cytochrome $b$ drawn following the results of the other 2 data sets (i.e. with Galeolaria hystrix and Spirobranchus cariniferus both monophyletic).

The models of nucleotide substitution for the Bayesian analyses were selected using the Akaike information criterion of Modeltest 3.7 (Posada \& Crandall 1998). The models selected for each gene region were submodels of $\mathrm{GTR}+\mathrm{I}+\mathrm{G}$ with more than 2 substitution types (i.e. $\mathrm{TrN}+\mathrm{G}$ for $18 \mathrm{~S}, \mathrm{TVM}+\mathrm{I}+\mathrm{G}$ for histone H3, and K81uf+G for cytochrome $b$ ); thus, it is more appropriate to use 6 , rather than 2 , substitution types with each gene. Bayesian analysis was performed using MrBayes v.3.1.2 with the maximum likelihood model employing 6 substitution types 
('nst $=6$ ') for each gene. For 18S and cytochrome $b$, rate variation across sites was modelled using a gamma distribution, for which none of the sites were invariant ('rates = gamma'). For histone H3 rate variation across sites was modelled using a gamma distribution, with a proportion of the sites being invariant ('rates = invgamma'). For the analyses the branch length priors were set to 'Unconstrained:Exponential(100)' to account for potential branch length estimation problems (see Brown et al. 2010). The Markov chain Monte Carlo searches were run twice with 4 chains for 5000000 generations, and trees were sampled every 100 generations. Convergence of the duplicate runs was assessed both in Tracer v.1.4 (Rambaut \& Drummond 2007) and via the average $\mathrm{SD}$ of split frequencies. Following this assessment, the first 10000 trees, i.e. 1000000 generations, were discarded as 'burnin' in each of the analyses.

Congruence with other measures of support was evaluated using NJ and MP bootstrap analyses. The NJ bootstrap analyses consisted of 10000 replicates using the model selected by Modeltest. The equally weighted MP bootstrap analyses consisted of 10000 replicates using a heuristic search (with TBR branchswapping).

\section{RESULTS AND DISCUSSION}

Our alignments resulted in a $1884 \mathrm{bp}$ fragment of 18S (43 taxa), a $313 \mathrm{bp}$ fragment of histone $\mathrm{H} 3$ (30 taxa) and a $383 \mathrm{bp}$ fragment of cytochrome $b$ (58 taxa). In the $1884 \mathrm{bp}$ fragment of $18 \mathrm{~S}, 1345 \mathrm{bp}$ were constant, $539 \mathrm{bp}$ were variable and 409 of the variable characters were parsimony informative. Of the $313 \mathrm{bp}$ fragment of histone H3, $205 \mathrm{bp}$ were constant, $108 \mathrm{bp}$ were variable and 98 of the variable characters were parsimony informative. Of the $383 \mathrm{bp}$ of cytochrome $b, 147 \mathrm{bp}$ were constant, $236 \mathrm{bp}$ were variable and 222 of the variable characters were parsimony informative.

The Bayesian phylogenies (Fig. 2) for each of the genes are broadly concordant with one another (while showing that each marker evolves at a different rate and, thus, has different levels of resolution). In each case (18S, histone H3 and cytochrome $b$ ) trees unequivocally place all our specimens of Galeolaria hystrix monophyletically together (the posterior probabilities and bootstrap support values show that this conclusion is well supported) irrespective of collection locality or mode of life. Similarly, Spirobranchus cariniferus all belong to a single species; all specimens group together and there is no difference among aggregated and solitary individuals (i.e. there is good posterior probability and bootstrap support for the monophyly of $S$. cariniferus).

Our genetic results conclusively disprove the hypothesis that ecological and lifestyle differences in the southern serpulid worms Galeolaria hystrix and Spirobranchus cariniferus result from cryptic species. The variation in bathymetric distribution and distinctive modes of life exhibited by these species must be explained using physiological and/or ecological drivers acting within species.

Interestingly, however, both the cytochrome $b$ and 18S trees show the Galeolaria hystrix individual collected from Adelaide, Australia, is separate from the New Zealand clade. As the type locality for $G$. hystrix is in New Zealand (Mörch 1863), this result suggests that the Australian species may require reexamination and possibly re-naming. In Australia, sequencing has split morphologically indistinguishable 'G. caespitosa' into an eastern clade (renamed G. geminoea) and a southwestern clade (real G. caespitosa) (Halt et al. 2009), whose cytochrome $b$ sequences differ by $>19 \%$. The Australian G. hystrix differs from our New Zealand clade by an average of $26 \%$ for the same gene. We note also that G. caespitosa and G. geminoea are both gregarious whereas the Australian G. hystrix is generally solitary (Halt et al. 2009).

Understanding the factors affecting serpulid reefbuilding is important far beyond serpulid systematics. Serpulid aggregations provide hard substrate and refugia for a wide variety of organisms and enhance biodiversity in the temperate waters where they occur (Haines \& Maurer 1980, Moore et al. 1998, Haanes \& Gulliksen 2011), as well as locally affecting water flow and sedimentation (Schwindt et al. 2004). Serpulid aggregations affect the local environment in other ways: they clean the water by filtering out particles as the worms feed (Davies et al. 1989); they also remove calcium carbonate from seawater for tube production, acting as a carbon sink (Medernach et al. 2000). Gregarious serpulids can thus be considered 'ecosystem engineers' (sensu Jones et al. 1994); understanding the causes of gregariousness is important for protection of their fragile and disappearing (see e.g. Hughes 2011) temperate ecosystems.

Physical environmental influences on reef distribution and growth have often been cited. A study of Serpula vermicularis reefs in Loch Creran, Scotland, showed that reefs were most common where suitable substrate (bivalve shells) was available, and that they did not occur in areas of strong currents (Moore et al. 1998). Similarly, the distribution of reefs formed by 

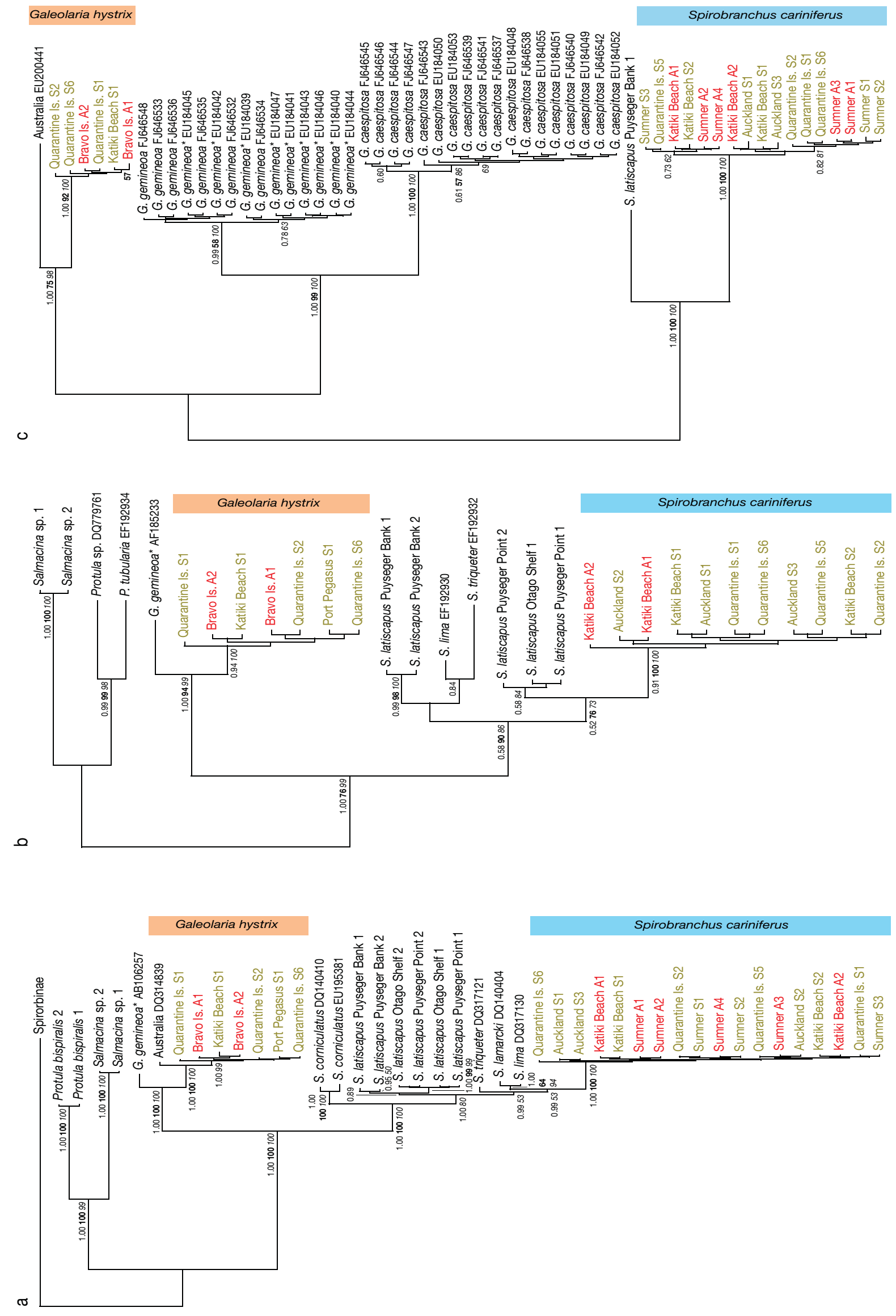

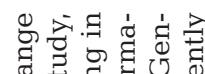

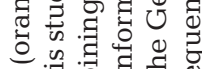

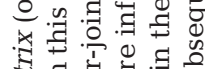

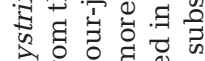

a

نे

त्र

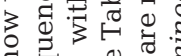

क ज्ञ

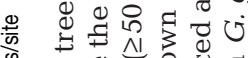

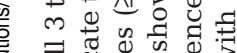

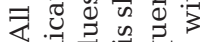

․․ㄹ

क

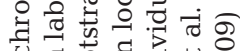

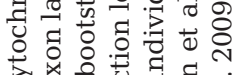

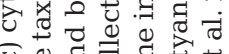

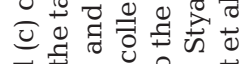

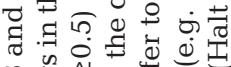

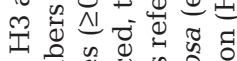

o

के द्वै दे है क्षे

글 융

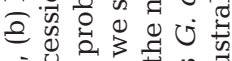

w

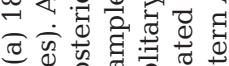

d.

की 0 की

है

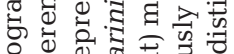

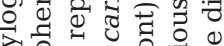

至行讨

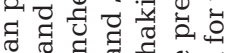

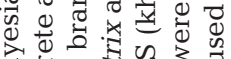

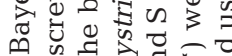

以.

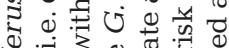

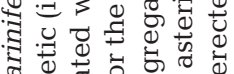

శึ

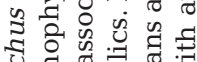

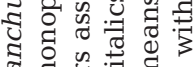

त्वै द्व

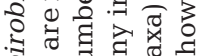

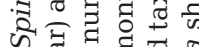

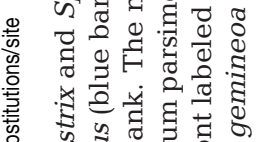

दे :

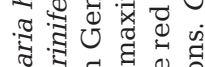

중 శี 명 छ

वे v

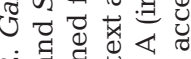

ن 
Ficopomatus enigmaticus in Mar Chiquita Lagoon, Argentina, appears to be affected by current speed, salinity and nutrient availability (Schwindt et al. 2004). Human activity, particularly anchor and mooring damage, can dramatically reduce serpulid reef abundance (Schwindt et al. 2004, Hughes 2011).

Biotic controls are less frequently invoked. For intertidal belt-forming (occupying a zone of the intertidal) species, ten Hove (1979) suggested that aggregation in serpulids might result from competition for food and space, at least at the lower limit. We know of no study that demonstrates biotic factors influencing serpulid reef distribution.

While physico-chemical environmental factors may influence growth of existing reefs, what exactly causes serpulid reef-forming to begin with? The most likely explanation is gregarious behaviour in larvae, perhaps influenced by chemical or physical attraction by adults (Kupriyanova et al. 2001). Serpulid larvae may remain in the water column up to 2 mo and are able to delay settlement under unsuitable conditions (ten Hove 1979). In some species, larvae may preferentially settle in areas where adult populations are dense, though only where tubes are whole; damaged tubes appear to repel larvae (summary in Kupriyanova et al. 2001). It is likely that larval behaviour, adult attractants and biotic or physical environmental factors combine to enable the onset of reef-forming in serpulid worms, though we cannot discount the possibility that genetic differences within species are also involved, perhaps underpinning some of the above factors.

The hypothesis that the different modes of life in these 2 species reflect the existence of cryptic species is conclusively disproved here. Some combination of larval behaviour, adult attractants, and other biotic or physical factors must be the drivers of reef formation, distribution and growth in these serpulid worms.

Acknowledgements. We acknowledge financial support from University of Otago summer studentship scheme. Specimens were collected by M. A. Riedi, G. O'Sullivan and V. C. Davis, with assistance from B. Dickson, P. Meredith, P. Heseltine and C. Garden. Some photos were provided by M. A. Riedi; K. Miller assisted with figure design. R. Hankey and $\mathrm{H}$. A. ten Hove kindly advised us on matters of Latin grammar; D. Lee and B. Marshall helped with ICZN nomenclatural rules. We acknowledge the contribution and improvement by anonymous reviewers.

\section{LITERATURE CITED}

Altschul SF, Gish W, Miller W, Myers EW, Lipman DJ (1990) Basic logical alignment search tool. J Mol Biol 215: 403-410
Bastida-Zavala JR, ten Hove HA (2002) Revision of Hydroides Gunnerus, 1768 (Polychaeta: Serpulidae) from the Western Atlantic region. Beaufortia 52:103-178

Bosence DWJ (1973) Recent serpulid reefs, Connemara, Eire. Nature 242:40-41

Brown JM, Hedtke SM, Lemmon AR, Lemmon EM (2010) When trees grow too long: investigating the causes of highly inaccurate Bayesian branch-length estimates. Syst Biol 59:145-161

> Colgan DJ, McLauchlan A, Wilson GDF, Livingston SP and others (1998) Histone H3 and U2 snRNA DNA sequences and arthropod molecular evolution. Aust J Zool 46: 419-437

> Davies BR, Stuart V, de Villiers M (1989) The filtration activity of a serpulid polychaete population (Ficopomatus enigmaticus (Fauvel) and its effects on water quality in a coastal marina. Estuar Coast Shelf Sci 29:613-620

Felsenstein J (1985) Confidence limits on phylogenies: an approach using the bootstrap. Evolution 39:783-791

Gray JE (1843) Chapter 10. Fauna of New Zealand. In: Dieffenbach E (ed) Travels in New Zealand; with contributions to the geography, geology, botany, and natural history of that country, Vol 2. John Murray, London, p 177-296

Haanes H, Gulliksen B (2011) A high local species richness and biodiversity within high-latitude calcareous aggregates of tube-building polychaetes. Biodivers Conserv 20:793-806

$>$ Haines JL, Maurer D (1980) Benthic invertebrates associated with a serpulid polychaete assemblage in a temperate estuary. Int Rev Gesamten Hydrobiol Hydrograph 65:643-656

Halt MN, Kupriyanova EK, Cooper SJB, Rouse GW (2009) Naming species with no morphological indicators: species status of Galeolaria caespitosa (Annelida: Serpulidae) inferred from nuclear and mitochondrial gene sequences and morphology. Invertebr Syst 23:205-222

Herbert DG (1993) Revision of the Trochinae, tribe Trochini (Gastropoda: Trochidae) of southern Africa. Natal Mus Ann 43:239-308

Huelsenbeck JP, Ronquist F (2001) MRBAYES: Bayesian inference of phylogeny. Bioinformatics 17:754-755

> Hughes DJ (2011) Where's the 'reef'? A five year study of serpulid tube bioerosion in a Scottish sea loch. Mar Ecol Prog Ser 430:273-280

> Jones CG, Lawton JH, Shachak M (1994) Organisms as ecosystem engineers. Oikos 69:373-386

Kupriyanova EK, Nishi E, ten Hove HA, Rzhavsky AV (2001) Life-history patterns in serpulimorph polychaetes: ecological and evolutionary perspectives. Oceanogr Mar Biol Annu Rev 39:1-100

Kupriyanova EK, Macdonald TA, Rouse GW (2006) Phylogenetic relationships within Serpulidae (Sabellida, Annelida) inferred from molecular and morphological data. Zool Scr 35:421-439

- Medernach E, Jordana A, Grémare A, Nozais C, Charles F, Amouroux JM (2000) Population dynamics, secondary production and calcification in a Mediterranean population of Ditrupa arietina (Annelida: Polychaeta). Mar Ecol Prog Ser 199:171-184

> Moore CG, Saunders GR, Harries DB (1998) The status and ecology of reefs of Serpula vermicularis L. (Polychaeta: Serpulidae) in Scotland. Aquat Conserv 8:645-656

Mörch OAL (1863) Revisio critica Serpulidarum. Et bidrag til rørormenes naturhistorie. Naturhistorisk Tidsskrift Henrik Krøyer, København (Ser 3) 1:347-470 
Morton J, Miller M (1973) The New Zealand sea shore, 2nd edn. Collins, London

Nardo GD (1847) Prospetto della fauna marina volgare del Veneto Estuario con cenni sulle principali specie commestibili dell'Adriatico, sulle venete pesche, sulle valli, ecc. In: Venezia e le sue lagune. G Antonelli, Venezia, p 113-156 (p 1-45 in reprint)

Norén M, Jondelius U (1999) Phylogeny of Prolecithophora (Platyhelminthes) inferred from 18S rDNA sequences. Cladistics 15:103-112

Posada D, Crandall KA (1998) Modeltest: testing the model of DNA substitution. Bioinformatics 14:817-818

Rambaut A, Drummond AJ (2007) Tracer, version 1.4. University of Edinburgh

Ronquist F, Huelsenbeck JP (2003) MRBAYES 3: Bayesian phylogenetic inference under mixed models. Bioinformatics 19:1572-1574

Schwindt E, De Francesco CG, Iribarne OO (2004) Individual and reef growth of the invasive reef-building polychaete Ficopomatus engimaticus in a south-western Atlantic coastal lagoon. J Mar Biol Assoc UK 84:987-993

Smith AM, McGourty CR, Kregting L, Elliot A (2005) Sub-

Editorial responsibility: Judith Grassle,

New Brunswick, New Jersey, USA tidal Galeolaria hystrix (Polychaeta: Serpulidae) reefs in Paterson Inlet, Stewart Island, New Zealand. N Z J Mar Freshw Res 39:1297-1304

Styan CA, Kupriyanova E, Havenhand JN (2008) Barriers to cross-fertlization between populations of a widely dispersed polychaete species are unlikely to have arisen through gametic compatibility arms-races. Evolution 62: 3041-3055

Swofford DL (2002) PAUP*. Phylogenetic analysis using parsimony ( ${ }^{*}$ and other methods). Sinauer Associates, Sunderland, MA

ten Hove HA (1979) Different causes of mass occurrence in Serpulids. In: Larwood G, Rosen BR (eds) Biology and systematics of colonial organisms. Systematics Association Spec Vol 11. Academic Press, London, p 281-298

ten Hove HA, Kupriyanova EK (2009) Taxonomy of Serpulidae (Annelida, Polychaeta): the state of affairs. Zootaxa 2036:1-126

ten Hove HA, van den Hurk P (1993) A review of recent and fossil serpulid 'reefs'; actuopalaeontology and the 'Upper Malm' serpulid limestones in NW Germany. Geol Mijnb 72:23-67

Submitted: February 22, 2012; Accepted: May 4, 2012 Proofs received from author(s): June 15, 2012 